\title{
Curriculum Design: Implementations and Challenges (Case Study of the English Language Center in Indonesia)
}

\author{
Restu Mufanti ${ }^{1}$, Elok Putri Nimasari ${ }^{2}$, Rohfin Andria Gestanti ${ }^{3}$, Happy Susanto ${ }^{4}$ \\ Faculty of Teacher Training and Education, Universitas Muhammadiyah Ponorogo, Indonesia ${ }^{1}$ \\ Faculty of Engineering, Universitas Muhammadiyah Ponorogo ${ }^{2}$ \\ Faculty of Social and Political Science, Universitas Muhammadiyah Ponorogo ${ }^{3}$ \\ Faculty of Postgraduate, Universitas Muhammadiyah Ponorogo ${ }^{4}$ \\ $\left\{{ }^{1}\right.$ restu.mufanti@umpo.ac.id\}
}

\begin{abstract}
As the crucial foundation of teaching learning process, curriculum should be well-designed by the curriculum developers. English curriculum in this language center has been developed years by years to find out an appropriate framework in order to provision students with certain abilities on English and the government pedagogical requirements. This study aims to seek the answers from purposive participants toward the three research questions; does the implemented curriculum meet the students' needs?, how are the curriculum of English certification programs designed?, what challenges do the curriculum developers face with in designing the curriculum?. A focus group discussion was used as the research approach to get in depth-data from participants. It was conducted for 12 hours. The research results illustrate that the designed-curriculum has met the students' need, internal institution policy and the development of other International tests. Likewise, the curriculum was designed by conducting need analysis, though the team encountered many challenges in designing it, for instance assessment and scoring.
\end{abstract}

Keywords: curriculum design, implementation, challenges.

\section{INTRODUCTION}

In recent decades, curriculum developers and government should make collaboration since the changes in social, economy, culture, industry, and technology have growth dramatically that demand the adaptable learners. The growth rate of technology as a means of communication in this century had brightened up the field of education, particularly the higher education [1]. A good curriculum ought to facilitate the students' need as well as the markets' need. As the formal organizations, university is in a central position that should improve the quality of the curriculum and its implementation. This is emphasized by UNESCO [2] that university has a significant role to design, evaluate, and improve the quality of curriculum. Curriculum is a system of planned actions for instruction and instruction is the system for putting the plans into action [3]. Curriculum is associated with learning experiences in the school in which teachers' action will influence the students' cognitive development. Permendikbud number 71 year 2013[4] states that curriculum aims to prepare Indonesia citizens to be competences in any aspects: religious, productive, creative, innovative, affective, and having contribution to the environment, social life and the global development. 
A number of scholars defines a curriculum differently, however they have a basic view on the concept of curriculum i.e a major plan or framework as a guidance book for teachers to teach their students. Curriculum involves elements that teacher should implement all principles to result expected-students. Therefore, curriculum developers should notice the principles in desgining curriculum. Macalister [5] points out curriculum design involving the integration of knowledge from many of the areas in the filed of Applied Linguitics, such as language acquisition research, teaching methodology, assessment, language description and materials production. It can be inferred that the elements in curriculum comprise goal, content, method and evaluation. Further, the elements of curriculum is divided into three major principles; they are content and sequencing, format and preparation, monitoring and assessment [5]. On the other hand, Cotterall [6] claims that there must be five principles for curriculum designers as the consideration in designing the curriculum for students: learner goals, the language learning process, tasks, learner strategies and reflection on learning. Thus, lead English Language Center to design the appropriate curriculum as what the students needs.

The fact that designing curriculum is not an easy action has been reported by many curriculum developers as well as the curriculum itself does not meet the students' needs and society. As a study conducted by Kwao [7] that there is no curriculum alignment in several of the instructions implemented at the Junior High School level despite their potential domains for human capital development. It is suggested that the school should revise the curriculum to reflect the best practices, prospects and opportunities for students. To add, a result of curriculum research also reveals that the taken-university as the research subject faces several challenges such as: the non-substitution of learning isntead of education, incomplete identification of the real needs of students and society and non-revision the curriculum to suit the changing needs, poor communication between levels of higher education curriculum and the previous degrees, centralization in curriculum planning, lack of flexibilty in curriculum, inadequate use of curriculum experts and disregarding role of faculty and student to develop the curricula [7]. Further, University has encountered many challenges and obstacles to fulfill the elements in designing the curriculum with learning society approach [8]. These studies illustrate that curriculum is impenatrable to design. Curriculum developers in institutions require experts in this field to assist the proper curriculum to meet the pupil's needs, society and markets.

Basically, educators are aware that curriculum as the crucial foundation of teaching learning process, should be well-designed. The need of developers knowledge on the concept of curriculum is also one of crucial factors to result the best plan. Thus, curriculum developers in institutions require curriculum experts to support, collaborate and to share the concept and the principles in designing it. However, books and articles regarding to this concept have been published wider, they still find tough to implement that concept into the plan. It seems working with curriculum means working with a house in which energy, thought, time and money should be available in the same time. Curriculum itself has been developed years by years to find out the appropriate framework for the sake of the students competency development on English and the government pedagogical requirements. As the other purpose of curriculum development is to control the teaching learning process making essential contributions on students with learning experiences, English language center as a supporting unit in a university which function is to serve students who want to enhace better English has designed the curriculum based on the students' need. Therefore, this article sets out to describe how English Language Center (ELC) in one university in Indonesia designed its English curriculum that can support students academic and working needs in challenges situations. Three research questions addresed are; does the curriculum designed meet the students' 
needs?, how is the curriculum of English certification program designed?, what are challenges the curriculum developers face with in designing the curriculum?.

\section{METHODOLOGY}

To answer the questions qualitative design was applied to search comprehensive data in depth. Qualitative research is often used for social science research; therefore, this research is appropriate to use this design. Mufanti and susilo [9] claims that a qualitative approach was applied in this present study as it provides ample opportunities to depict and describe the behavior of the subjects in giving feedback in greater depth, and their perspectives could be maintained to complement the data obtained. Focus group discussion was conducted to gather the information from the curriculum developers relating to the curriculum designed for the English certification program particularly English for academic purpose and the challenges encountered by the developers in designing that curriculum.

\subsection{Research Subject}

Purposive method was used to determine the appropriate subjects involved in this research. The researchers also involved in this research as active participants. Nyumba et.al.[10] confirm that focus group discussion aims to obtain data from a purposely selected group of individuals rather than from a statistically representative sample of a broader population. Moreover, they [10] also recommend using purposive sampling because focus group discussion relies on the ability and capacity of participants to provide relevant information. This research, there were six subjects purposively taken from the curriculum developers, institution authority, a language centre head, one curriculum developer coordinator, and three members of curriculum developer. They were gathered in a round table to discuss curriculum development for their institution and challenges faced in constructing that curriculum. These group discussions were conducted for four times. Then, a supporting staff recorded these activities to help the researchers remember all words and utterances produced during the discussions session.

\subsection{Data Collection Technique}

To collect the data, a focus group discussion (FGD) was used as the research technique to get comprehensive and complete data from the curriculum team. FGD is frequently used as a qualitative approach to gain an in-depth understanding of social issues [10]. Moreover, it is explained that FGD is a research technique in which researchers assembles a group of individuals to discuss a specific issue, purposing to illustrate the experiences, beliefs, perceptions and attitudes of the personals though interaction [10]. FGD was conducted for four times in which for each meeting run around 3 hours, therefore the total time of group discussion was around 12 hours.

\subsection{Data Analysis}

The data taken from FGD was analysed descriptively by implementing set of investigating including listing, coding, analysing conversation (words uttered by subjects). In details, while the researchers involved in conversation, they also observed the utterances produced by the subjects. Additionally, it was supported by recording to crosscheck the correct statements. Then, the results of observation were listed and coded. Furthermore, the conversation was 
analysed. Before writing a report, researchers validated to the participants to improve the credibility of the findings. As stated by Nyumba et. al., [10] researchers should share the findings with the participants of the research to emphasize points to improve the credibility of the study, it is called as member checking. Finally, the results of analysing conversation were narratively described and concluded.

\section{FINDINGS AND DISCUSSION}

The first focus group discussion (FGD-1) addressed the issue of whether the implementedcurriculum met the students' needs. The second FGD talked about how the participants designed the curriculum for English certification program. The challenges that the participants faced in designing the curriculum was the third issue discussed in FGD.

\subsection{Does the implemented curriculum meet the students' needs? (FGD-1)}

For overview, currently, this institution applied two certification programs; English for speech (public speaking/PS), English for academic purpose namely Standardized Test of Academic English Proficiency (STAcEP). The two programs were taken by all students in the first semester and sixth semester respectively. The purposes of giving those programs were; while PS aims to enable students to speak English in front of audience confidently and fluently, STAcEP aims to enable students to have competency in academic English so students understand other international tests, for instance IELTS, TOEFL and TOEIC. PS program has been researched last year, and then the results reveal that PS could build students'confidence and reduce their anxiety. Moreover, this study also shows that this program is appropriate for vast major students; even PS intensive course is better given than giving English in general context[1]. Speaking, compared to other skills, is required for students particularly undergraduate students. As claimed by Susilo [11] that speaking is one of the English skills that should be mastered as the necesity not only to communicate well in academic purpose but also for professional one.

Accordingly, these programs are appropriate for non-English major students with several reasons in which the reasons were gotten from need analyzes they did before implementing those of. Further, they claimed that reasons to decide offering two programs were students' conditions, institutional policy and International tests of English. In details, PS was offered because the students do not have this facility from their study program since their study program merely offered English for Specific Purposes (ESP), consequently the English Units should give other materials that can facilitate them to enable with English speaking ability. On the other hand, STAcEP was provided to enable students with an academic English so that they could use this competence to take another International tests commonly used both in this country and another countries. Thus, the team developed the curriculum involving those two programs. Then, a question comes out whether the curriculum designed meet the students' need?. The team needs to discuss and review the curriculum.

Accordingly, the team conducted need analysis by distributing questionnaire to the targeted students. Need analysis also was gathered data from the institution authority and market demands. The data got from those need analysis led the curriculum developers to construct a curriculum that facilitate students with their needs. All participants confirm that this curriculum was proper with the students' need, policy and the demand of markets; even they all suggest other English service units in other universities to apply the similar programs. In details one participant, a coordinator, explained as a unit which understands the students and institution situation, we should able to design good curriculum in restricted conditions. 
The conditions in this context means limited time and limited students' financial. However, the limitations would not be the factors to construct qualified curriculum. One member also strongly stated that "we put all our thought, energy and time to create a proper curriculum by understanding the students' situation, but we must also aware with market demands". She added "we always think how the designed-English curriculum should give benefits to the students in English competency context. According to focus group discussion, all research subjects claim that the curriculum has met the students' need. They added that in the mid of 2016, they consulted and verified their English curriculum of the certification program to three curriculum experts. As a result, the curriculum designed received some comments and critiques to revise. They have revised it from 2017 to present to get better curriculum.

Regarding to what students' needs and condition, participants confirmed that students expect to be able to speak English and to have academic English proficiency. Nevertheless, they have limited time due to full time studying in their own study program and limited budget to pay additional English courses. Consequently, the team ought to create a curriculum that could give them an English course under those conditions. The authority said that most of their students come from poor, working, and lower middle class therefore he and other policy makers in that institution had to make a wise decision. They decided to design programs that cover two abilities; public speaking and STAcEP. The former was designed to enable students on public speaking with a minimum standard score at Basic level. On the other hand, the later was designed to enable students with academic English with a minimum standard score 41 that aligned to CEFR (Common European Framework References) is A2.

A coordinator curriculum developer, additionally, explained about a test designing for academic English as the type of assessment used in this program. This test is created due to the expensive English test held by language testing services. The prestige certificates issued by those institutions are accepted by vast majorities of prestigious universities and companies in this world to continue study and to work. Nonetheless, most undergraduate students have not required it yet. Thus, the team provided a test that can prepare the students once they will take international tests; they will be ready for it. The certificate issued in this institution may be accepted by other institutions or countries as well as the other international tests in the future.

In this view, all participants concur that the implemented-curriculum and the designed-test for the students meet the students need. Following are points to conclude the findings:

1. The curriculum was designed to introduce English in higher level

2. The curriculum was designed due to the internal institutional policy

3. The curriculum was designed by considering the students condition (time and financial)

4. The curriculum was designed by considering the demand of the market

5. The curriculum was designed to enable students to speak publicly

6. The curriculum was designed to prepare students to be able to pass the International test such as IELTS and TOEFL.

7. The team designed their own tests, namely STAcEP

8. The team issued two certificates for two program

9. The team believed that STAcEP will be accepted by other institutions

10. The team confirmed that the curriculum meets the students' need.

\subsection{How the curriculum of English certification programs are designed?. (FGD-2)}

This session investigated how the curriculum for PS and STAcEP programs were designed. Every participant in this meeting expressed much more clear statements than in 
session 1. It seems they more understand in this issue than the first issue. The discussion revealed that the curriculum was designed by conducting need analysis. They analyzed the need of English by asking to the policy makers of the institution, analyze the students' situation and analyze the market needs. After they got data from those explorations, they set the programs and the goals. The goals determined the standard competences should the students have. Afterwards, they set the materials, the time, the teaching methods, the assessments, and evaluations. Last, they designed a certificate that was given in the end of the program. In detailed, firstly, they conducted need analysis to decide the goals, they applied taxonomy of cognitive adapted from Bloom, Anderson and Krathwol. As Susanto [12] emphasizes that designing curriculum should classify the learning goals start from the lowest cognitive to the highest one; remembering, understanding, applying, analyzing, evaluating and creating. Next step was composing the learning outcomes. Afterwards, the team designed the materials used. The design was completed with learning experiences such as teaching strategy and media, assessment and evaluation. Susanto [13] highlights that designing curriculum should entail learning goal, learning materials, learning experiences, time allotment, media and teaching strategies and assessment and evaluation. The coordinator told that they use those principles. The participants also confirmed that they checked the result of curriculum to the experts and test it to students from other universities. The materials, the methods and the tests are regularly updated every year by regarding the students and the market conditions.. The designed tests were Public Speaking test and STAcEP test in which they aligned the score to the CEFR, then, it must be converted to other scores of International tests. This phase took almost 3 years and currently is being evaluated to get better output.

As what the curriculum coordinator explained, principally, there are numbers of books and theory explain about curriculum designs, yet the implementation is not simple. There are other aspects should be considered such as the students conditions, the university conditions, the location of the university, the local characters of the society, the needs of English in that institutions, the financial. These aspects influenced the way the developers laid out the curriculum. As it is overlooked by Susanto [13]that conceptually, a wider country, different demography, geography, economy, and culture are factors should be well considered in designing curriculum. Thus, they designed the curriculum as follow:

1. Conducting need analysis

2. Setting goals and programs

3. Designing the materials

4. Designing the learning process

5. Designing the tests

6. Conducting evaluations

7. Checking and consulting to experts

\subsection{What challenges do the curriculum developers face with in designing the curriculum? (FGD-3)}

The third FGD was to understand the challenges encountered by curriculum team. Susanto [13] confirms that in the level of implementation, designing curriculum and its syllabus found challenges; even it is not easy to overcome the challenges. In this stage, most of participants have similar problems. They all said designing test items and marking the tests in STAcEP was much complicated than PS. However, work on score descriptors has similar level of difficulty both on PS and STAcEP. Some score references were searched to have pictures on how to work on those areas. Still, they said it was the hardest thing to do, i.e. analysing and 
understanding the words in CEFR and adapting it to the programs. During designing the curriculum, they said that they often argued each other to state their ideas; nevertheless, a final decision must be taken and concurred.

Then, other challenges exactly encountered by the team as what the head said that there was a gap between the expected standard and the students' input especially on STAcEP. In the pilot test, it reveals that the expected standard score was 41 at basic, yet the students' score mostly was under 40 at pre-basic. Thus, team has tough tasks to minimize the gap by revising the curriculum in evaluation phase. Other participants talked about learning activities problems. The curriculum was set to have standard learning activities such as some students are less motivated, most of the students have full scheduled in their own study program, and other students are lack of discipline. Though, consequently, the learning process could not work as the programmed-curriculum. Another discussed their challenge are about how to standardize the language tests for STAcEP they designed and how to design the tests that based on the students' need and the market needs. Still, they all concur that designing academic tests, for instance STAcEP are hard part in constructing curriculum. Designing test, further, they confirmed that work on it almost 4 years and the results were far from a good test. Thus, team always try to revise it many times until now to have better tests which they expect that the tests would be accepted by other parties. Team also invited several experts of curriculum and language assessment to help them understanding constructing tests.

A question posted by researchers; if constructing curriculum needs energy, time, financial and brilliant thought, why they do not make some collaborations with other prestigious parties whether to conduct the course or the merely tests. We can notice that a number of good English programs offered by other credible parties. They responded that they could not make any collaboration with them due to the students' financials as the costs offered are too expensive until theey could not afford to pay it. Given that, they tried to design their own curriculum for English programs and tests that can facilitate students to learn English and experience with English tests.

From that information, it can be pointed the challenges faced by the team, as follow:

1. Assessment phase: designing test items and marking the tests

2. Analysing and understanding the words in CEFR and adapting it to the programs

3. A gap between the expected standard and the students' input especially

4. The learning process could not work as the programed-curriculum

5. Difficulty in designing the tests that based on the students' needs and the market needs

\subsection{Check and Confirmation (FGD 4)}

The last FGD was conducted to tell participants the results of the findings. The participants ought to know the results and may make any clarifications if they find inappropriate statements and conclusions. The head said that the results were clearly correct and could be issued. Accordingly, the results of the study help them to find out their problems and limitations in designing curriculum. She said, based on those findings, she would find the solutions to overcome those of. In this session, the authority also asked the researchers to emphasize his statements that expensive tests conducted by tests services from other parties burden their students. Based on that consideration, he made a decision to create affordable tests. 


\section{CONCLUSIONS}

To conclude, according to the findings, the curriculum designers emerged two programs, namely Public Speaking and STAcEP. The former program is designed to fulfill the students' need on speaking; on the other hand, the latter is designed to facilitate the students with test of academic English preparation. They designed their curriculum based on the theory of curriculum and considered the students' need, internal institutional policy and market demands. However, some challenges found, for instance designing test for STAcEP. Thus, they have tried to find solutions to overcome their challenges such as getting research grants to support their programs in designing better curriculum and tests.

\section{Acknowledgments.}

The researchers should say thank you to Directorate for Researches and Community Services, Directorate General of Research Empowerment and Development, Ministry of Research, Technology and Higher Education (KEMENRISTEKDIKTI) under Grant 27 Maret 2019 in the year of 2019-2020 who supports this research by giving sufficient funds. All researchers also are greatly grateful to the Research and Community Service Institution, Universitas Muhammadiyah Ponorogo that facilitate to access the grant and all authorities of English Language Center who support this research well.

\section{References}

[1] R. A. Gestanti, E. P. Nimasari, R. Mufanti, and U. M. Ponorogo, "TEACHING ENGLISH FOR INTERNATIONAL STUDENTS FROM NON-," no. 2, pp. 179-191, 2018.

[2] "Unesco Recomendaciones.".

[3] MacDonald, "No Title," in True Discipleship, 1965.

[4] E. P. Nimasari, "Evaluating an EFL Textbook: To What Extent Does The 2013 Curriculum-Based Textbook Accomplish Pedagogical Aspects?. on,” Proceeding Int. Conf. Teach. Train. Educ., vol. 1, 2016.

[5] J. Macalister, Language Curriculum Design. 2010.

[6] S. Cotterall, "Promoting learner autonomy through the curriculum: Principles for designing language courses," ELT J., vol. 54, no. 2, pp. 109-117, 2000.

[7] A. Kwao, "Challenges of Curriculum Design and its Implications on Policy: The Case of the Junior High School (JHS) Teaching Subjects in Ghana," J. Educ. Soc. Res., vol. 7, no. 2, pp. 93-101, 2017.

[8] N. Longworth, "Enthusing and Empowering Learners," 2004.

[9] R. Mufanti and A. Susilo, "Bridging the Gaps Between Students' Prior Knowledge and Skills in Writing and the Expected Thesis Outcomes," JEES (Journal English Educ. Soc., vol. 2, no. 2, p. 101, 2017.

[10] T. O.Nyumba, K. Wilson, C. J. Derrick, and N. Mukherjee, "The use of focus group discussion methodology: Insights from two decades of application in conservation," Methods Ecol. Evol., vol. 9, no. 1, pp. 20-32, 2018.

[11] A. Susilo, "Academic Controversy Model As an Alternative Strategy for Teaching Speaking At University Level," Cendekia J. Kependidikan dan Kemasyarakatan, vol. 11, no. 2 , p. $285,2016$. 
[12] Susanto, Telaah Kurikulum 2013Yang Telah Melalui Proses Pengembangan dan Perbaikan. Surabaya, 2016.

[13] Susanto, Pengembangan KTSP dengan Perspectivef Manajemen Visi. Surabaya, 2007. 